\title{
TRANSLATOR'S PREFACE AS A GENRE: A COMPARATIVE ANALYSIS OF LITHUANIAN AND ENGLISH PREFACES
}

Summary. Translations serve as a right to the international existence as they allow the national literature to reach wider audiences. Moreover, they allow readers to get acquainted with literature of other cultures. For these reasons, translators have an important role in the literary world. Translators' prefaces are the main link between readers and translators. However, there is a lack of analysis of this specific genre. This research aims at analysing translator's preface as a genre and examining differences and similarities of genre features in Lithuanian and English prefaces. 30 Lithuanian and 30 English translators' prefaces are analysed according to genre elements, such as the format, genre moves and functions. The analysis covers a wide range of examples of both Lithuanian and English fiction books. For this reason, the analysed translators' prefaces are published in different years, are translated by different translators and are published by different publishing houses. It may be noted, that the analysis reveals that Lithuanian translators tend to be more invisible in their prefaces than English translators. They focus on the author and provide little of their own evaluation and explicit explanations on translation issues. However, English translators focus on the translation process and the subjective analysis. The analysis also demonstrates that the basic format of prefaces is beginning with a title and ending with a signature.

Keywords: translator; translator's preface; genre; genre analysis; format; genre moves; function; translations.

\section{Introduction}

A translator is a mediator between readers and books as he / she provides an opportunity to enjoy literature from a variety of cultures. Translations are essential in all countries as a way to find out more about traditions of other cultures. The importance of translations raises a question about the translators' role in specific societies. A translator's preface is one of the means for translators to show their presence in books. These prefaces are the closest material surrounding a translation as translators use them to convey the background information and explanations of the translation process. The structure and the style of translators' prefaces reveal the means that translators compose their role and presence in different societies. This research 
aims to examine and compare genre perspectives of translators' prefaces in Lithuanian and English examples. This comparison allows to better understand the features of the translators' role in Lithuania when compared to a wider society of English translators. Moreover, this comparison is used as a basis for the genre analysis as there is a lack of analysis of Lithuanian translators' prefaces. The data has been collected by selecting translated books into Lithuanian and English and searching for translators' prefaces. 30 Lithuanian and 30 English books with a translator's preface have been selected for the analysis. The chronological scope of the analysis is 1900-2016. Examples have different translators, publishing houses and source languages. The selection aimed at covering a wide range of examples in both Lithuanian and English books. Descriptive and comparative methods are used to discuss prefaces. The research uses the methodology of genre analysis and draws on the methods of corpus linguistics.

\section{Translator's preface as a genre}

Gérard Genette (1987, p. 160) first coined the term translatorial preface in his classification of types of prefaces and at first the term was analogous to the term "authorial preface," but later became translator's preface. However, according to Maryam Hosseinzadeh (2015, p. 311), there is an assumption that there should not be any translatorial prefaces attached to the literary work. The author provides an example of Gayatri Chakravorty Spivak (2015) who took note of the mean notice for writing a preface to the work of fiction she translated which was in sharp contrast with the abundant praise she received for her preface on a volume of philosophical criticism (Hosseinzadeh, 2015 , p. 311). In addition, the author explains that with this negative approach to translator's preface on fictions, the non-fiction translators have a privilege as prefaces are often welcomed in this genre thus allowing the translator to explain the strategies used in the translation (Hosseinzadeh, 2015, p. 311). In other words, in fiction translations, translators are more praised for being invisible (Hosseinzadeh, 312). Moreover, M' Carmen Buesa Gómez (2003) claims that translators' prefaces are not analysed enough as the studies continue to be geared towards the analysis of the translations and the attention towards prefaces is justified in relation to the biography of the translator (2003, 
p. 187). These prefaces are not put in any context in order to collect the influences amongst them or to deduce from the information contained in them the theoretical directions which are proposed by translators (Gómez, 2003, p. 187). Translator's preface has an ambivalent status due to references to both the author's work and the translator's own rendering of it (Gómez, 2003, p. 189). This invisibility can be changed as translator's preface is the story of the translator, the story of self and an ontological narrative and for these reasons it is the public sphere for translators to raise their voice and make it heard (Hosseinzadeh, 2015, p. 312). Translator's preface has a constructive role in shaping the public, conceptual and meta narratives on the concept of translation and translator (Hosseinzadeh, 2015, p. 312). Furthermore, prefaces are important documents in Translation Studies as they indicate: (1) challenges, (2) decision making, (3) preferences, agency, (4) positioning, (5) identity and other not fully investigated questions (Hosseinzadeh, 2015, p. 312). Despite this importance, there is a lack of comprehensive framework for the analysis of translator's preface as a genre (Hosseinzadeh, 2015, p. 312). The reason for this is that approaches in Translation Studies have been utilizing different materials but have overlooked the closest materials surrounding the translation, such as preface (Hosseinzadeh, 2015, p. 313). However, there are possible points for the analysis of translator's preface: (1) The title as translators tend to use different terms for labelling their prefaces; (2) The length as longer texts tend to have longer prefaces and vice versa; (3) The pagination which reveals if the preface follows the same format as the whole text; (4) The signature which shows how translators refer to themselves (Hosseinzadeh, 2015, p. 315). Moreover, functions that translator's preface can have are important in the analysis of this genre and they can be: (1) explanatory which refers to explanations of problems and reasons for deciding how to solve them; (2) normative / prescriptive which contributes to prefaces' furnishing guidelines to be followed by translation practitioners and critics; (3) informative / descriptive which introduces the source text, the source author and the sociocultural context of the source (Hosseinzadeh, 2015, p. 317).

Xia Jing-yi and Sun Zhi-xiang (2015, p. 1081) claim that translators' prefaces are important because they provide the information concerning the original and the author, for example, characters' information, but also 
explain the motivation for the translation and adopted strategies. Moreover, the focus of the content of translator's preface has shifted from the author to the translation process which reflects translator's subjectivity (Jing-yi \& Zhixiang, 2015, p. 1081). The authors emphasize that in-depth analysis of this genre is important for the development of translatology as it contributes to recognition and visibility of the translator's status (Jing-yi and Zhi-xiang, 2015, p. 1081). Translators' prefaces begin to form their own framework, display functions and occupy an important position in Translation Studies (Jing-yi and Zhi-xiang, 2015, p. 1088). The authors present and explain 11 points that are divided into more and less frequent, which are covered in translators' prefaces:

Table 1.

The points covered in translator's preface (based on Jing-yi and Zhi-xiang, 2015, p. 1083-1085)

\begin{tabular}{|l|l|}
\hline $\begin{array}{l}\text { Frequent points covered in translators' } \\
\text { prefaces }\end{array}$ & $\begin{array}{l}\text { Rare points covered in } \\
\text { translators' prefaces }\end{array}$ \\
\hline $\begin{array}{l}\text { The translator's opinion or analysis of the } \\
\text { plots or author's writing purpose (translators } \\
\text { show their presence as the opinion is } \\
\text { subjective) }\end{array}$ & Definition of the genre \\
\hline $\begin{array}{l}\text { Statements of intent (setting the story takes } \\
\text { place in, theme of the novel) }\end{array}$ & $\begin{array}{l}\text { Contextual information (related } \\
\text { information about a serial of works) }\end{array}$ \\
\hline Brief introduction to the original work & Introduction to the translated version \\
\hline Introduction to the author & Introduction to the translator \\
\hline $\begin{array}{l}\text { Translator's conclusion about the process of } \\
\text { translation (problems, strategies used) }\end{array}$ & Commentary of the title \\
\hline $\begin{array}{l}\text { Genesis of the work (how the original work } \\
\text { was created) }\end{array}$ & \\
\hline
\end{tabular}

\section{Comparison of Lithuanian and English translators' prefaces}

The format, functions and genre moves are analysed in 30 Lithuanian and 30 English translators' prefaces from, specifically, fiction books published in the time period of 1900-2016. The comparison shows not only the basic characteristics of this genre but also indicates differences between Lithuanian and English translators' prefaces. The first analysed aspect of this genre is the format which is looked at according to four elements: 
Table 2.

The format of Lithuanian and English translators' prefaces

\begin{tabular}{|l|l|c|c|}
\hline \multirow{2}{*}{ Title } & \multicolumn{2}{|l|}{$\begin{array}{l}\text { Lithuanian } \\
\text { prefaces }\end{array}$} & English prefaces \\
\hline \multirow{3}{*}{ Length } & Have the title & 28 & 30 \\
\cline { 2 - 4 } & No title & 2 & 0 \\
\hline \multirow{3}{*}{ Pagination } & 1 page or less & 4 & 6 \\
\cline { 2 - 4 } & More than 1 page & 26 & 24 \\
\cline { 2 - 4 } & Same format as the text & 25 & 8 \\
\cline { 2 - 4 } & Different format & 0 & 14 \\
\cline { 2 - 4 } & No pagination & 5 & 8 \\
\hline \multirow{3}{*}{ Signature } & Name, the translator & 28 & 2 \\
\cline { 2 - 4 } & Date, place & 0 & 9 \\
\cline { 2 - 4 } & No signature & 2 & 2 \\
\hline
\end{tabular}

Table 2 shows that the biggest part of Lithuanian translators' prefaces (95\%) and all English instances (100\%) start with the title. Only 5\% of Lithuanian translators' prefaces has no title which suggests that titles are commonly used in this genre by Lithuanian and English translators. Interestingly, only 3 instances from 28 prefaces with titles name it as translator's preface in Lithuanian books. The examples are as follows: Vertejo pastabos (x2) and Vertejos pratarmé. Other examples contain titles which reflect the author or the book, for instance, Apie autoriy (x6), Apie autoriy ir jo knyga (x3) and Apie poeta $(x 2)$. These titles show that the focus in Lithuanian examples is not on the translation process but on the information about the author. On the other hand, 6 out of all prefaces with titles in English have the title without mentioning the translator: Introduction (x3), Afterword, Acknowledgements and Preface. Other prefaces have titles such as Translator's preface (x8), Translator's note (x10), Translator's preface and acknowledgements, Translator's afterword and Translator's introduction (x2) and these titles clearly state who has written the text. The obvious difference in Lithuanian and English prefaces proves that translators in English case tend to indicate their role in prefaces and translations, whereas Lithuanian translators do not emphasize their contribution to the text in the title.

Moreover, $87 \%$ of Lithuanian prefaces and $80 \%$ of English instances are longer than a page. These results indicate that longer texts are a common length of this specific genre. In addition, longer prefaces in both cases demonstrate that translators provide more information and explanations. In addition, Table 2 shows that even $84 \%$ of Lithuanian prefaces has the same 
format pagination as the text, $16 \%$ has no pagination and none have different format than the text. These results indicate that Lithuanian prefaces are regarded not as a separate text but as a part of the whole book. On the other hand, the same format does not separate the preface as a very different text with a distinct purpose than the translated text and this reduces the importance of the translator's preface. As seen in Table 2, 27\% of English examples has the same format pagination, $54 \%$ has different and $27 \%$ no pagination. This reveals that English translators tend to use different pagination in their prefaces and exclude their text from the rest of the book.

The last aspect of format is the signature, which reveals that the majority of Lithuanian (94\%) and English (64\%) translators' prefaces end with the name of the translator or the word translator. Interestingly, 8 instances out of all Lithuanian prefaces with the signature end with only a word translator, whereas there are no such cases in English examples. However, more English translators' prefaces (30\%) compared to Lithuanian (7\%) end with no signature at all. Translators tend to be visible in prefaces as they provide their full names for readers to be able to find out more about them and their works. The signatures and titles with only a word translator suggest a circular structure of prefaces and refer to the translator but not to a specific person. The arguably similar results show that beginning with a title and ending with the full name of the translator is the basic translators' prefaces format in Lithuanian and English data. The analysis of the format shows that prefaces tend to be long, with the title and the signature of the translator in both cases which suggests that translators show their presence and direct contributions in translations. However, the difference in titles reveals that English translators focus on their contributions to the text and Lithuanian translators focus on the author and the book instead.

The second important aspect analysed is genre moves (components which describe communicative intentions which a particular portion of the text realizes in relationship to the overall task contributing to the fulfilment of the overall communicative purpose of the genre (Connor, Davis and De Rycker, 1995, p. 463-464)). Lithuanian and English examples are looked at according to 11 basic genre moves used in translators' prefaces and introduced by Jingyi and Zhi-xiang (2015). Table 3 reveals the numbers of prefaces out of 30 Lithuanian and 30 English that include each specific genre move: 
Table 3.

Genre moves of Lithuanian and English translators' prefaces

\begin{tabular}{|l|c|c|}
\hline- & $\begin{array}{c}\text { Lithuanian prefaces } \\
\text { (out of 30 in total) }\end{array}$ & $\begin{array}{c}\text { English prefaces } \\
\text { (out of 30 in total) }\end{array}$ \\
\hline $\begin{array}{l}\text { The translator's opinion or analysis } \\
\text { of the plots or author's writing } \\
\text { purpose }\end{array}$ & 23 & 17 \\
\hline Statements of intent & 24 & 15 \\
\hline $\begin{array}{l}\text { Brief introduction to the original } \\
\text { work }\end{array}$ & 15 & 14 \\
\hline Introduction to the author & 23 & 17 \\
\hline $\begin{array}{l}\text { Translator's conclusions about the } \\
\text { process of translation }\end{array}$ & 8 & 6 \\
\hline Genesis of the work & 12 & 13 \\
\hline Definition of the genre & 4 & 18 \\
\hline Contextual information & 18 & 10 \\
\hline $\begin{array}{l}\text { Introduction to the translated } \\
\text { version }\end{array}$ & 7 & 0 \\
\hline Introduction to the translator & 0 & 13 \\
\hline Commentary of the title & 3 & \\
\hline
\end{tabular}

As seen in Table 3, the first common genre point in Lithuanian and English instances is the translator's opinion on the plot or the author's writing purpose. The results show that $77 \%$ of Lithuanian prefaces and $57 \%$ of English contain the translator's analysis and this proves that this genre move is regarded as one of the basic points in both Lithuanian and English prefaces. For example:

(1) Šioje knygoje I. Bergmanui rūpi menininko pasaulis, jo sielą draskantys konfliktai, aistros, kūrybiniai ieškojimai, nesėkmès (Neištikimoji: romanas, 2003, p. 140).

(2) My father wrote his memoir of Auschwitz in late 1945 and 1946, with the experiences of the camp still fresh in his mind. He was then 48 years old. He wrote what he saw and heard around him: human stories as diverse and different as people are, human behavior from the highest and most noble to the lowest and most base. He chose to write in Yiddish, the language used by and accessible to the Jewish communities living in countries around the world for whom his record was intended (Sky tinged red, 2014, p. x).

These examples suggest that translators tend to explain the author's writing purpose. However, bigger number of Lithuanian prefaces (77\%) compared to English (57\%) shows that Lithuanian translators emphasize the author's writing purpose more than English translators. The second genre point found in prefaces is the statement of intent where the translator provides the information about the story's setting and theme. For example: 
(3) Graudžiai visame romane apdainuojamas be tèvo augęs ir jo besiilgintis Nealas Cassady, nejausdamas menkiausio sąžinès graužimo, po visą Ameriką barsto savo vaikus (Kelyje, 2016)

(4) Egilio šeimos priešistorè sutampa su Norvegijos valstybès kūrimosi pradžia, konungo Haraldo Gražiaplaukio pastangomis itvirtinti savo žiaurią valia, triuškinant mažesnes karalystes ir laisvuosius bondus (ūkininkus) (Egilio saga, 2012, p. 13).

(5) It tells a tale of adventure in the raw Siberian wilds where even sex and violence make an occasional appearance, though with a connection to the plot-line quite unlike their counterparts in any work of fiction I have read (Anastasia, 2008, p. 150).

(6) The previous novel, Urfin Jus and his Wooden Soldiers, left a few matters unexplained (Tales of Magic Land 2, 2009, p. 396).

All examples reveal that translators explain the overall setting of the text in their prefaces. The explanations are long and detailed which suggests that this information is regarded as important by translators. $80 \%$ of Lithuanian prefaces include the statement of intent, but only $50 \%$ of English instances contain this information. Even though both Lithuanian and English translators include the statement of intent often, the difference ( $80 \%$ and $50 \%$ ) proves that Lithuanian prefaces focus on the original text more than English.

The third genre move that is used comparably similarly in Lithuanian and English prefaces is the brief introduction to the original work. For instance:

(7) Romana Mobis Dikas, arba banginis $1851 \mathrm{~m}$. spalio $18 \mathrm{~d}$. Lodone pirmąkart išleido Richardas Bentley. Išcenzūruoto tritomio pavadinimas buvo Banginis. Jam stigo epilogo, be kurio knyga pristatantys kritikai negalejo suprasti, kaip imanomas pasakojimas pirmuoju asmeniu, jei visi laivo igulos nariai paskendo (Mobis Dikas, arba banginis, 2016, p. 2).

(8) School of Freedom (Jiyū gakkō) was a best-selling novel in the 1950s, and Shishi Bunroku was among Japan's most widely read authors of the Showa era (1926-89). The novel was selected for the Japanese Literature Publishing and Promotion program because it stands out as a work of refined humor in the era of modern Japanese fiction (School of freedom, 2006, p. 242).

Table 3 reveals that $50 \%$ of Lithuanian prefaces and $47 \%$ of English prefaces include the information about the original work. This shows that it is equally important in all prefaces. Another genre point found in the analysis is the introduction to the author. In addition to the introduction to the original 
work, translators provide the information about the author's past and this shows that the author's life is considered as important for readers. For example:

(9) Jaunystèje A. Burgessas daug laiko skyrè muzikai, sukūrè nemažai didelès apimties muzikiniu veikalu (Prisukamas apelsinas, 2014, p. 7).

(10) Hansas Kristianas Andersenas pasakas ir istorijas rašè kone visą savo, kaip rašytojo, gyvenimą: pradejo "Pasaku, pasektu vaikams" pirma knygele su šauniuoju "Skiltuvu" ir dar trimis pasakomis (Dvylika iš pašto karietos, 2015, p. 1).

(11) Volkov is in top form in The Seven Underground Kings (Tales of Magic Land 2, 2009, p. 396).

(12) Shishi Bunroku is the penname adopted by Iwata Toyoo (1893-1969) when he turned to professional writing to support his family after his second marriage in 1934 (School of freedom, 2006, p. 242).

Extracts suggest that the introduction to the author is important in this genre. However, Lithuanian prefaces include this information more often (77\%) than English (60\%) and this difference further proves that Lithuanian translators tend to emphasize the importance of the author in their prefaces.

One more genre point analysed in prefaces is translator's conclusions about the process of translation where translators explain the strategies that they used, the problems that they encountered and the solutions for these problems. For instance:

(13) Skaitydami Mobi Diką lietuviškai tikriausiai neatkreipiame dèmesio, kad dabar lietuviu kalboje isitvirtinęs "banginis" smarkokai skiriasi nuo šio vandens žinduolio pavadinimu kitomis kalbomis. Šio žodžio kilmę patyrinèjo ir aprašè "Banginis mūsu raštijos bangose" - lietuviu kalbos žodžiu istorijos žinovè Birutė Kabašinskaitè (Mobis Dikas, arba banginis 2016, p. 3).

(14) It took nearly two years to translate the whole thing (Sky tinged red, 2014, p. xii).

Table 3 reveals an interesting shift in the results among Lithuanian and English prefaces. Translator's conclusions are provided in $27 \%$ of Lithuanian examples and in $57 \%$ of English ones and this indicates bigger focus of English translators on the translation process compared to Lithuanian translators. This difference in the focus is further proved with the addition of the genesis of the work where 
translators explain the way the original work was created providing additional information about the author. For example:

(15) Mirdamas rašytojas paliko du romano „Dvišakas liežuvis" (The Double Tongue, 1993) juodraščius apie vèlyvaja helenistinę Graikija, tapusią Romos imperijos geografine provincija, nors vis dar likusia intelektualiniu centru (Dievas skorpionas; Dvišakas liežuvis, 1998, p. 1).

(16) When we went through his papers after he died in 1960, we found three type-written copies of a manuscript, composed on an old Yiddish typewriter that he had left behind in Germany (Sky tinged red, 2014, p. xii).

Table 3 reveals that this genre move is used in $40 \%$ of Lithuanian texts and in $20 \%$ of English prefaces. This percentage suggests that this genre move is comparably rare. The difference in the usage between Lithuanian and English translators proves bigger focus on the original book in Lithuanian prefaces.

One more genre move analysed in the prefaces is the definition of genre. Translators tend to provide an explanation of genre of the original book for readers to better comprehend the translated text. For example:

(17) First - the book reads like a novel (Anastasia, 2008, p. 150).

(18) Ši patirtis turètu ne tik praturtinti, bet ir paruošti pažinčiai su tokiu savitu, atitikmens pasaulineje literatūroje neturinčiu reiškiniu, kuri priimta vadinti "islandu saga / saga apie islandus" arba "giminiu saga" ir konkrečiu jos pavyzdžiu "Egilio, Skalagrimo (arba Plikagalvio, Plikojo Grimo) sūnaus, saga" (Egilio saga 2012, p. 12).

However, this genre step is rarely found in the examples. $14 \%$ of Lithuanian prefaces explain the genre and only $4 \%$ of English contain this information. The difference shows that Lithuanian translators tend to provide more information regarding the original text. Moreover, the contextual information as a genre move is found in prefaces. This information is related to a serial of works and translators explain the relations of the specific translated text and other works of the author. For instance:

(19) He started another journal - "The Epoch," which within a few months was also prohibited (Crime and Punishment 2006). 
(20) Nors žiemišku Anderseno pasaku yra nedaug, tarp ju randame kaip tik tas, kurios daugeliui pačios brangiausios: "Sniego karalienę", "Eglutę", „Sniego seni". Šiame rinkinyje kartu su jomis - ir "Bokšto sargas Olë", "Nykštukas ir prekijas", mūsu skaitytojams dar negirdèta "Dvylika iš pašto karietos" (Dvylika iš pašto karietos. Žiemos pasakos, 2015, p. 1).

Examples reveal the importance of the contextual information in both Lithuanian and English prefaces. Table 3 shows that $60 \%$ of Lithuanian and 44\% English prefaces contain this information and this difference further proves that Lithuanian translators focus on the author more than English translators.

The introduction to the translated version is found as a common genre move. These introductions include explanations and descriptions of the translation and how the original work influenced it. The examples of the introductions in Lithuanian and English prefaces are as follows:

(21) The copy was difficult to read, so I decided to transliterate it first into Latin script, then use the transliteration, which I could read more quickly, to translate into English (Sky tinged red, 2014, p. 2).

(22) Taip pat teko nekaitomus, lietuviu kalbos taisyklèms nepaklūstančius žodžius skirti kursyvu, to pats autorius nedaro: originale rusiški žodžiai - dažniausiai iškraipyti niekaip neskiriami, su jais elgiamasi visiškai taip pat kaip su angliškais (Prisukamas apelsinas, 2014, p. 4).

Instances show that both Lithuanian and English translators tend to introduce the translated version in their prefaces. However, only $24 \%$ of Lithuanian instances and even $60 \%$ of English ones contain this information. These results suggest a clear difference in the focus of prefaces. The results show the tendency of English prefaces to give the priority to the translation, whereas Lithuanian examples prove that the text itself is more important. Similarly to the information about the translated version, translators include the introduction to the translator. For instance:

(23) Over the twenty years since my mother's death, I have received various forms of support, including two sabbaticals, for my work on Marie from Linfield College, where I teach (The Journal of Marie Bashkirtseff, 2013). 
$35 \%$ of English examples include the direct introduction to the translator. English translators describe themselves in detail and directly state their contributions. However, no information about the translator is found in Lithuanian examples. This reveals that Lithuanian translators do not provide the introduction to themselves and do not include this as a genre move, whereas English translators focus on their accomplishments.

The last genre move found in the analysed prefaces is the commentary of the title where translators explain the specificities of the book title. For example:

(24) Tai liudija jo paties suredaguotas termino apibrèžimas, "Random House" leidyklos itrauktas i žodyno "American College Dictionary" 1959 m. leidimą: "Palūžusioji karta - po Antrojo pasaulinio karo atejusios kartos atstovai, veikiausiai dèl šaltojo karo sukeltos nusivylimo pasirenkantys mistini atsiribojima ir socialinio bei seksualinio griežtumo nepaisymą, [beat (BEATEN var.) (Kelyje, 2016).

Table 3 shows that $10 \%$ of Lithuanian prefaces explain the title. On the other hand, none of English instances have this information. This difference clearly reveals that this genre move is not used by English translators. However, Lithuanian translators tend to include it as additional information about the original book.

In addition, the analysis reveals that there are points covered in these prefaces which are not mentioned in the theory. For instance, the comparison of the book to other popular books of that time, excuses for translation decisions (25), the history of Georgia and the information about translations of the book into other languages (26):

(25) $<\ldots>$ patyrę italianistai tesiteikia man atleisti (Moteris Casanovos laikais, 2007).

(26) <...> ji išversta i estu, čeku, slovaku, vengru, vokiečiu kalbas (Kiekvienas, kurs mane ras..., 1986, p. 442).

The additional genre moves are also found in English examples. For instance, a story of the translator who had a firsthand experience of the story in the book: 
(27) The freedom of my youth and the carefree pre-war years ended abruptly when Hitler invaded Poland (Sky tinged red, 2014, p. xi).

The example shows the connection of the translator to the text while revealing the translator's past. This analysis shows that translators tend to use not only genre moves suggested by scholars but also include additional information. Regarding the specific language, the prefaces do not use terms, but use specialized expressions, such as autorius, romanas, vertimas, leidimas and they are the same in all prefaces. To exemplify, the common structure and language:

(28) Iš viso rašytojas yra parašęs daugiau kaip trisdešimt knygu (Prisukamas apelsinas, 2014, p. 9)

(29) Antrasis rašytojo romanas (Kiekvienas, kurs mane ras..., 1986, p. 442).

(30) A. Strindbergas sukuria visa šūsni nauju stambiu veikalu (Raudonasis kambarys: Hemsio salos žmonės, 1989, p. 399).

Examples suggest that language expressions are similar in this genre in Lithuania. In addition, English prefaces do not use translation terms, but use specialized expressions, for example, translations, author, translator and are consistent throughout all examples. The common structure and language can be seen in examples:

(31) $\langle\ldots\rangle$ there were two Russian words that presented a particular translation challenge (Anastasia, 2008, p. 3).

(32) Two of the pieces in this collection have already been published in translation (Beginning with my streets, 2010).

Examples indicate the basic sentence structure and language used in prefaces and it is noticeable that it mainly refers to the translation process. Lithuanian and English translators do not use translation terminology, but rather include simpler language for all readers to be able to understand everything. The analysis reveals the main difference in the focus of Lithuanian and English translators. English translators explain the translation process, introduce themselves and provide their opinions. On the other hand, Lithuanian translators use long descriptions of the author's life, his / her previous works and the analysis of the book. This difference demonstrates that the main focus 
in English examples is on the translation and Lithuanian translators focus on the author providing less information about the translation itself.

The last aspect analysed is functions of Lithuanian and English prefaces. The numbers of prefaces with specific functions are as follows:

Table 4.

Functions of Lithuanian and English translators' prefaces

\begin{tabular}{|l|c|c|c|}
\hline & $\begin{array}{c}\text { Explanatory } \\
\text { function }\end{array}$ & $\begin{array}{c}\text { Normative / } \\
\text { prescriptive function }\end{array}$ & $\begin{array}{c}\text { Informative / } \\
\text { descriptive }\end{array}$ \\
\hline $\begin{array}{l}\text { Lithuanian } \\
\text { prefaces }\end{array}$ & 2 & 0 & 28 \\
\hline $\begin{array}{l}\text { English } \\
\text { prefaces }\end{array}$ & 9 & 3 & 18 \\
\hline
\end{tabular}

According to Table 4, the informative / descriptive function is the most common in Lithuanian examples (94\%) but is less common in English instances (60\%). Prefaces with this function introduce the author, the book and provide an overall description. For instance:

(33) Tikriausiai daug kas iš jūsu skaitè Dž. R. R. Tolkino knyga "Hobitas". (Žiedu valdovas, 1994, p. 8)

(34) Ōba would readily admit that he was not the first scholar to examine Qing-dynasty (1644-1912) cultural relations with Japan of the Edo (Tokugawa) period (1600-1867), but he was without a doubt the most active (Books and Boats, 2012, p. vii).

Examples show how translators introduce the author. However, a clear difference in the comparison of Lithuanian (94\%) and English (60\%) prefaces suggests that Lithuanian translators focus on the author more than English. The second analysed function is explanatory where translation problems and solutions are provided. For example:

(35) $<\ldots>$ užuot pateikusi Prancūzijos publikai pažodini vertima, nusprendžiau perteikti ju dvasią. (Moteris Casanovos laikais, 2007).

(36) Readers may be surprised to see that a number of texts and newspaper articles appear in the original Greek. There are two main reasons for this (Migrant: The Blessing and Misfortune of Loving two Countries, 1998). 
Instances demonstrate the importance of describing the translation process in prefaces. Interestingly, only $7 \%$ of Lithuanian prefaces and even $30 \%$ of English include this information. This difference proves that Lithuanian translators tend to emphasize the author and the book instead of explaining the translation process. The last function is normative / prescriptive which contributes to furnishing guidelines of the preface:

(37) As always, and with undiminished gratitude, I want to thank the author for his generous and invaluable assistance, and our editor, Drenka Willen, for her sensitive reading of the text and her cogent suggestions and stimulating questions (Baudolino, 2003, p. 522).

This function is found in $10 \%$ of English prefaces which reveals that it is rarely found in this specific genre. The results show that none of Lithuanian examples have this function which states that furnishing guidelines are not regarded as important by Lithuanian translators. These results confirm that this genre is mainly used to introduce the author and explain the translation process. The results of the function analysis show that Lithuanian translators write their prefaces to introduce the author and the theme of the book, but arguably rarely use their prefaces to explain the translation process. On the other hand, English translators tend to focus more on the translation process.

\section{Conclusions}

The analysis of genre features of Lithuanian and English translators' prefaces demonstrated similarities, for instance, all English examples contain the title and the majority part includes the translator's signature at the end. Moreover, the majority of Lithuanian prefaces includes the title and the signature. This demonstrates that this is the basic format for the translator's preface. In addition, low percentage of Lithuanian and English examples include the definition of genre and the commentary of the title in their genre moves. This suggests that these specific genre moves are rarely used by Lithuanian and English translators. Finally, translators use simple language without specific translation terms for all readers to be able to understand their preface. 
The analysis also revealed certain differences between Lithuanian and English prefaces according to genre features. For example, the majority of titles of Lithuanian prefaces contains the information about the author, whereas English instances have titles about the translator. This proves that English translators directly name their preface and Lithuanian translators tend to remain invisible. Furthermore, bigger part of Lithuanian translators' prefaces has the same format of pagination as the text and bigger part of English prefaces has different format. This means that English translators exclude their texts from the rest of the book and Lithuanian translators consider their prefaces as a part of the whole book. Additionally, English translators' prefaces include more information about the translation process and the translator's opinion in their structure. They contain the introduction to the translated work and translator's conclusions of the translation process. However, Lithuanian examples demonstrate more information about the author and the original book with the statement of intent and the introduction to the author. This difference shows that the main focus is on the translation in English and on the author in Lithuanian prefaces. Finally, the informative / descriptive function is found more often in Lithuanian prefaces than in English examples. In addition, the explanatory function is used more often by English translators. This suggests that Lithuanian translators emphasize the introduction to the author, whereas English translators tend to also explain their translation process.

Similarities and differences in genre moves reveal that Lithuanian and English translators' prefaces are similar in the format, but the main focus is on the translation and the translator in English prefaces and on the author and the book in Lithuanian. This proves that Lithuanian translators are arguably invisible in published books and tend to focus on the author in their prefaces.

\section{Sources}

Andersen, H. C. (2015). Dvylika iš pašto karietos. Transl. Liudas Remeika. Vilnius: Alumnus.

Bergman, I. (2003). Neištikimoji: romanas. Transl. Zita Mažeikaitè. Vilnius: Alma littera.

Burgess, A. (2014). Prisukamas apelsinas. Transl. Saulius Dagys. Vilnius: Sofoklis. 
Chiladze, O. (1986). Kiekvienas, kurs mane ras.... Transl. Aldona Baliulienè. Vilnius: Vaga.

Dostoevsky, F. (2006). Crime and Punishment. Transl. Constance Garnett. Retrieved from https://www.gutenberg.org/files/2554/2554-h/2554h.htm

Eco, U. (2003). Baudolino. Transl. William Weaver. London: Vintage.

Eiger, I. (2014). Sky Tinged Red. Transl. Dora Eiger Zaidenweber. Minnesota: Beaver's Pond Press.

Elisabeth, R. (2007). Moteris Casanovos laikais. Transl. Irina Mikalkevičienè. Vilnius: Vaga.

Golding, W. (1998). Dievas skorpionas; Dvišakas liežuvis. Transl. Irena Varnaitè and Aleksandra Dantaitè. Vilnius: Vaga.

Kernberge, K. (Ed.) (2013). The Journal of Marie Bashkirtseff. Transl. Katherine Kernberge. New York: Fonthill Press LLC.

Kerouac, J. (2016). Kelyje. Transl. Irena Balčiūnienè. Kaunas: Jotema.

Kouris, A. (1998). Migrant: The Blessing and Misfortune of Loving Two Countries! Transl. Ben Petre. Crete: Heraklion.

Megré, V. (2008). Anastasia. Transl. John Woodsworth. New York: Ringing Cedars Press.

Melville, H. (2016). Mobis Dikas, arba banginis. Transl. Irena Balčiūnienè. Vilnius: Baltos lankos.

Miłosz, C. (2010). Beginning with my Streets. Transl. Madeline G. Levine. New York: Farrar, Straus and Giroux.

Osamu, Ō. (2012). Books and Boats. Transl. Joshua A. Fogel. Portland: MerwinAsia.

Shishi, B. (2006). School of Freedom. Transl. Lynne E. Riggs. Michigan: University of Michigan.

Skallagrímsson, E. (2012). Egilio saga. Transl. Svetlana Steponavičienè. Vilnius: Aidai.

Strindberg, A. (1989). Raudonasis kambarys: Hemsio salos žmonès. Transl. Eugenija Stravinskienè. Vilnius: Vaga.

Volkov, A. (2009). Tales of Magic Land 2. Transl. Peter L. Blystone. New York: Red Branch Press.

Tolkien, J. R. RI. (1994). Žiedu valdovas. Transl. Andrius Tapinas. Vilnius: Alma littera. 


\section{References}

Connor, U., Davis, K., \& De Rycker T. (1995). Correctness and clarity in applying for overseas jobs: a crosscultural analysis of U.S. and Flemish applications. Text 15.4, 457-476.

Genette, G. (1987). Paratexts: Thresholds of Interpretation. Cambridge: Cambridge University Press.

Gómez, M' C. B. (2003). The Preface as a Genre in English Translations in the 17th Century. Retrieved from https://www.google.It/?gws_rd=ssl\#q=Preface+as+a+Genre+in+En glish+Translations+in+the+17th+Century.

Hosseinzadeh, M. (2015). Translatorial Prefaces: A Narrative Analysis Model. International Journal of English Language, Literature and Translation Studies, 2/3, 311-319.

Jing-yi, X. \& Sun Z. (2015). Changing Content of Translator's Prefaces: with Special Reference to China Yilin Press's Translated Publications. Journal of Literature and Art Studies, 5/11, 1081-1089.

\section{Milda Bikmanienè}

Vytauto Didžiojo universitetas, Lietuva; milda.bikmaniene@vdu.It

\section{VERTĖJO PRATARMĖS ŽANRAS: LIETUVIŠKU IR ANGLIŠKU PRATARMIU LYGINAMOJI ANALIZE்}

Santrauka. Vertimai suteikia teisę i tarptautini egzistavimą, nes leidžia nacionalinei literatūrai pasiekti platesnę auditorija. Be to, jie suteikia skaitytojams galimybę susipažinti su kitu kultūru literatūra. Dèl šiu priežasčiu vertėjai atlieka svarbu vaidmeni literatūros pasaulyje. Vertejo pratarmè - pagrindinè sąsaja tarp vertejju ir skaitytoju, tačiau šis žanras yra mažai analizuojamas. Šio tyrimo tikslas yra ištirti vertejjo pratarmès žanro ypatybes ir atskleisti žanro bruožu skirtumus ir panašumus lietuviškose ir angliškose pratarmèse. 30 lietuvišku ir 30 anglišku vertèjo pratarmiu analizuojamos atsižvelgiant i žanro bruožus: tokius kaip formatas, žanro požymiai ir funkcijos. Analizejje apžvelgiami ivairūs lietuvišku ir anglišku grožinès literatūros knygu pavyzdžiai. Analizuojamos knygos yra išleistos skirtingais metais, skirtingu leidyklu ir išverstos skirtingu vertejju. Analizè atskleidžia, kad lietuviu vertejjai yra linkę būti mažiau matomi savo pratarmèse nei anglu vertejjai. Daugiausiai dèmesio lietuviai skiria rašytojui, mažiau kalba apie teksto vertinima ir tiksliu problemu, iškilusiu verčiant teksta, paaiškinimą. Anglu vertejjai plačiau apibūdina vertimo procesa ir pateikia subjektyvia teksto analizę. Tyrimas taip pat parodo, kad pavadinimas teksto pradžioje ir parašas pabaigoje pagrindinis pratarmès formatas.

Pagrindinès sąvokos: vertejjas; vertejjo pratarmè; žanras; žanro analizè; formatas; žanro požymiai; funkcija; vertimai. 